\title{
Effect of vacuum pressure on Yamú fish (Brycon amazonicus) meat during cold storage
}

\author{
Efeito da pressão de vácuo na carne de peixe Yamú \\ (Brycon amazonicus) durante o armazenamento refrigerado
}

\author{
Daniel Castañeda Valbuena ${ }^{1 *}$ (1), Sandy Luz Ovando Chacón', \\ Ana Carolina Torregroza-Espinosa ${ }^{2}$, Héctor Suárez Mahecha ${ }^{3}$
}

\author{
${ }^{1}$ Tecnológico Nacional de México/Instituto Tecnológico de Tuxtla Gutiérrez, Departamento de Ingeniería Química y \\ Bioquímica, Tuxtla Gutiérrez, Chiapas - México \\ ${ }^{2}$ Corporación Universidad de la Costa (CUC), Grupo de Investigaciones en Desarrollo Agroindustrial Sostenible \\ (GIDAS), Ingeniería Agroindustrial, Barranquilla, Atlántico - Colombia \\ ${ }^{3}$ Universidad Nacional de Colombia, Instituto de Ciencia y Tecnología de Alimentos (ICTA), Bogotá - Colombia
}

*Corresponding Author: Daniel Castañeda Valbuena, Tecnológico Nacional de México/Instituto Tecnológico de Tuxtla Gutiérrez, Departamento de Ingeniería Química y Bioquímica, Carretera Panamericana, km 1080, 29000, Tuxtla Gutiérrez, Chiapas - México, e-mail: dacasval@gmail.com

Cite as: Castañeda Valbuena, D., Ovando Chacón, S. L., Torregroza-Espinosa, A. C., \& Suárez Mahecha, H.

\begin{abstract}
This study aimed to assess the cryoprotectant effect of vacuum packaging ( 35 and $45 \mathrm{kPa}$ ) on cold preserved $\left(0^{\circ} \mathrm{C}\right.$ and $\left.-18^{\circ} \mathrm{C}\right)$ fillets of Yamú (Brycon amazonicus), during 5 days of storage. We analyzed the physicochemical and microbiological changes in the fillets during storage time. Yamú's water holding capacity, nitrogenated bases content (TVB-N) and texture (N) were affected $(p \leq 0.05)$ by time and temperature. Bacterial colonies in fillets did not represent a risk for human health after five days of storage. In conclusion, vacuum packing positively $(p \leq 0.05)$ reduces the effect of cold over Yamú fillets properties.
\end{abstract}

Keywords: Yamú fillets; Cold preservation; Vacuum storage; Quality; Physicochemical characteristics.

\section{Resumo}

O objetivo deste trabalho foi avaliar o efeito crioprotetor de embalagens a vácuo (35 e $45 \mathrm{kPa}$ ) em filés de Yamú (Brycon amazonicus) conservados a frio $\left(0{ }^{\circ} \mathrm{C} \mathrm{e}-18{ }^{\circ} \mathrm{C}\right)$, durante cinco dias de armazenamento. As alterações físico-químicas e microbiológicas foram analisadas nos filés durante o armazenamento. A capacidade de retenção de água, o teor de base nitrogenada (BTV-N) e a textura (N) foram influenciados $(p \leq 0,05)$ pelo tempo e pela temperatura. Colônias bacterianas em filés não representaram risco à saúde humana após cinco dias de armazenamento. $O$ uso de embalagem a vácuo apresentou efeito significativo positivo $(p \leq 0,05)$, reduzindo o efeito do frio sobre as propriedades dos filés.

Palavras-chave: Filés de Yamú; Conservação a frio; Armazenamento a vácuo; Qualidade; Características físico-químicas. 


\section{Introduction}

Accelerated world population growth will increase food demand, with a projected increase of $70 \%$ by 2050 (Ørnholt-Johansson et al., 2017). Demand increase poses a challenge to food producers, particularly to industries focused on protein production, processing and commercialization, such as fisheries (Ravindran \& Jaiswal, 2016). Innovations in aquaculture production provide an alternative to fishing industry producers through the development of culture technologies for new species, and improvement of those already cultured. At the same time, fish processing and commercialization industries need to strengthen their meat preservation technologies.

It is of vital importance not only to keep food pathogen-free, but also to guarantee freshness, sensory characteristics and overall quality.

Freshness is one of the main attributes to assess fish quality, which requires reliable methods and techniques (Hashimoto et al., 2017). Fish loses freshness and undergoes a marked decay after death due to the disruption of cell structure, and other biochemical processes promoted by microorganism growth and endogenous enzyme activity (Ocaño-Higuera et al., 2009). These alterations negatively affect the fish organoleptic properties during cold storage, particularly if preservation lasts for long periods. Texture and water retention capacity are some of the characteristics most affected by cold storage (He \& Xiao, 2016; Sánchez-Alonso et al., 2012; Wang et al., 2018). The extent of these changes differs among fish species, and depends on such diverse factors as fish physiological condition, microbial contamination, management/handling methods and storage conditions (Ando et al., 1999). The drastic postmortem changes in fish meat texture have been attributed to factors such as pre-slaughter handling, slaughter method and amount of fat in muscle, as well as storage time and temperature (Li et al., 2017; Yu et al., 2018). Freezing is not only one of the most efficient methods to extend shelf life of food products, but it also contributes to their security and safety. In the European Union (EU), for example, it is mandatory by law that fish products for human consumption, raw or preserved, are processed through light treatments such as salting, smoking, or margination (European Union, 1991). It is also mandatory for fish products to be frozen to $-20^{\circ} \mathrm{C}$ or below, for at least $24 \mathrm{~h}$ in order to kill parasites that might be present within the product (Sánchez-Alonso et al., 2012). However, the organoleptic properties of fish during cold storage may be negative affected, particularly if preservation lasts for long periods.

Many studies have been carried out in order to analyze the quality of frozen fish and determine the differences in the stability of various fish species stored frozen under the same conditions (Simeonidou et al., 1997; Soto-Valdez et al., 2015). There are two main problems associated with frozen storage of fish: hydrolysis and oxidation of lipids and protein denaturation. These problems cause an off-taste and a dry texture (Simeonidou et al., 1997).

The extent of these changes differs among fish species, and depends on such diverse factors as fish physiological condition, microbial contamination, management/handling methods and storage conditions (Ando et al., 1999). The softening of fish meat has been studied in marine (Ladrat et al., 2003; Wang et al., 2009) and freshwater fish species (Suárez-Mahecha et al., 2007; Wang et al., 2011). However, these studies have focused on highly commercial species (Suárez-Mahecha et al., 2007), and that have a vital role in global food security, especially in countries with high levels of poverty (Anderson et al., 2017). In this regard, the Yamú (Brycon amazonicus) stands out as a fish with farming potential in Colombia, Brazil and other South American countries. It is considered a species of high commercial interest due to its good acceptance in the consumer market, rapid growth and easy handling of food from its early stages of reproduction (de Barros et al., 2019). Nevertheless, one of the main difficulties to market this specie is the effect of cold storage of drastically affects over quality characteristics, like the texture and water retention capacity of its meat. When stored at low temperatures, Yamú meat has rapid softening. Currently, it is not known with certainty which factors cause this or through which mechanisms (Ladrat et al., 2003). Authors have suggested that texture losses in fish meat in cold storage is caused by the effect of proteases (Verrez-Bagnis et al., 1999), 
especially cathepsins, calpains and hydrolytic enzymes such as elastase and collagenase (Chéret et al., 2007). In this sense, it is important to perform a more comprehensive study on the behavior of Yamú meat subjected to conservation processes. Therefore, this study aimed to evaluate the cryoprotectant effect of vacuum packaging on cold preserved fillets of Yamú (Brycon amazonicus), during 5 days of storage.

\section{Material and methods}

\subsection{Biologic material collection}

We used two batches of Yamú fish (Brycon amazonicus) from the Meta department, Colombia. One batch was obtained from a fish farm located in the municipality of Cumaral. Crop specimens are usually bred under the following conditions: stock density of 1 to 1.5 individuals $/ \mathrm{m}^{2}$ with water temperature ranges of 26 to $30^{\circ} \mathrm{C}, \mathrm{O}_{2}$ dissolved between 4 to $7 \mathrm{mg} / \mathrm{L}$, a pH between 6 to 7 . We used commercial fish feed containing between 20 and $-30 \%$ crude protein, and alternative supplementation with leaves and fruits (Arias, 2006); whereas the second batch was wild caught from the Meta River in the Vereda San Miguel - Pescadero, municipality of Puerto Gaitán. Fish from river has an omnivorous and opportunistic diet. But, Yamú prefers to consume plant products, especially fruits and seeds (Arias, 2006). All animals were sacrificed with a blow to the head, and immediately sent to the laboratory in expanded polystyrene coolers with ice in plastic bags, avoiding contact between ice and fish.

\subsection{Fillet preparation}

Fish were washed using cold water $\left(5 \pm 1.5^{\circ} \mathrm{C}\right)$, eviscerated and filleted. Fillets from cultured and wild caught fish were separated and randomly assigned to each treatment (T1, T2, T3, T4, T5 and T6), and three replicates of each treatment was used to quantify variations and increases the precision of measurements. $\mathrm{T} 1$ and $\mathrm{T} 6$ were composed by fillets conserved at $0{ }^{\circ} \mathrm{C}$ and $-18{ }^{\circ} \mathrm{C}$ respectively and without vacuum into polyethylene bags. These groups were used like a control in order to highlight the effect of pressure for each temperature of storage. $\mathrm{T} 2$ and $\mathrm{T} 5$ were fillets conserved at $0{ }^{\circ} \mathrm{C}$ and $-18{ }^{\circ} \mathrm{C}$ under $35 \mathrm{KPa}$ of vacuum. Finally, $\mathrm{T} 3$ and T4 were fillets conserved at $0{ }^{\circ} \mathrm{C}$ and $-18{ }^{\circ} \mathrm{C}$ and packaged under $45 \mathrm{KPa}$. Fillets conserved under vacuum conditions used a normal vacuum packaging in flexible bags. All fillets were storage during 5 days. Previous studies show that Yamú meat has rapid softening when is stored at low temperatures (after 12 hours) (Suárez-Mahecha et al., 2007).

\subsection{Laboratory analysis}

Texture, water retention capacity (WHC), total volatile base nitrogen (TVB-N), color, $\mathrm{pH}$ and microbiological test were analyzed on each treatment and replicated daily during five days of storage.

\subsection{Texture}

A Stable Micro Systems texture analyzer (TA.XT2, Surrey, England) was used to measure texture as describe with a flat end cylinder $(10 \mathrm{~mm}$ in diameter, $\mathrm{P} / 10$ type $)$ that was pressed against the muscle tissue. All of the tests were done at $5{ }^{\circ} \mathrm{C}$, keeping the fillets in Petri dishes on ice. Three replicates (cubes $2 \times 2 \times 1.2 \mathrm{~cm}$ ) were taken from each fillet, from the top of the sideline. The response variable was the maximum cutting force ( $\mathrm{g} \mathrm{g}^{-1}$ sample). A compression test was done before the test: $1.00 \mathrm{~mm} \mathrm{~s}^{-1}$, test speed: $1.10 \mathrm{~mm} \mathrm{~s}^{-1}$, speed after test: $10.00 \mathrm{~mm} \mathrm{~s}^{-1}$, distance between the cylinder and sample: $15.0 \mathrm{~mm}$, compression of the sample: $40.0 \%$. The conditions were the same for each sample and seven measurements were taken for each meat portion (Larsson et al., 2014). 


\subsection{Water Holding Capacity (WHC)}

The water holding capacity (WHC) was determined used the methodology described by SánchezAlonso et al. (2012) for three replicates per fillet. $3 \mathrm{~g}$ of meat were taken and wrapped in two filter papers (Whatman No. 1, $110 \mathrm{~mm}$ diameter) and placed in a falcon tube. Subsequently, they were centrifuged for $15 \mathrm{~min}$ at 3,000 $\mathrm{g}$. Then, the paper was removed and the samples were weighed. The WRC was expressed as a percentage of water retained by the sample after centrifugation.

\subsection{Total Volatile Base Nitrogen (TVB-N)}

Total volatile base nitrogen was measured using the method described by Ramezani et al. (2015) with some modifications. The method consisted a direct distillation of fish muscle homogenates (10:100 muscle: water). The homogenates were shaken every 10 minutes. The resulting mixture was centrifuged at $3000 \mathrm{rpm}$ for $10 \mathrm{~min}$. The supernatant was filtered through a filter paper (Whatman No. 1, $110 \mathrm{~mm}$ diameter). From the filtrate, $5 \mathrm{~mL}$ were obtained and mixed with $5 \mathrm{~mL}$ of $10 \mathrm{~g} / \mathrm{L}$ of magnesium oxide $(\mathrm{MgO})$. The phase of steam distillation was carried out using a Kjeldahl distillation unit for $5 \mathrm{~min}$. The distillate was absorbed by $10 \mathrm{~mL}$ of a solution of $20 \mathrm{~g} / \mathrm{L}$ boric acid, titrated with $0.1 \mathrm{~mol} / \mathrm{L}$ of $\mathrm{HCl}$. The results were expressed as TBV-N mg N/100 g. This experiment was carried out by triplicate.

\section{$2.7 \mathrm{pH}$}

The samples $\mathrm{pH}$ was analyzed following the methodology described by Mohan et al. (2007), in which a homogenized sample was held with cold deionized water $\left(0 \pm 0.5^{\circ} \mathrm{C}\right) 1: 6$, using a homogenizer (Ultra-Turrax IKA T-25, Campinas, Brazil) at 10,000 rpm for $1 \mathrm{~min}$. Once the homogenate was obtained, the reading was taken with a $\mathrm{pH}$ meter $\left(17 \pm 1.5^{\circ} \mathrm{C}\right)\left(\mathrm{JENWAY}{ }^{\circledR}, \mathrm{JW}-3505\right.$, Staffordshire, UK). Five measurements were taken for each of three replicates.

\subsection{Microbiological analyses}

This analysis was performed following the methodology reported by Kachele et al. (2017). The microbiological tests were carried out each day that the fillets remained stored $(0,1,2,3,4$ and 5$)$. These samples (72) were transferred to individual sterile Petri dishes in order to avoid contamination. For each sample of fillet, $90 \mathrm{~mL}$ buffered peptone water (APB) was used. This mixture was then homogenized to produce the initial dilution; then serial dilutions were made adding $1 \mathrm{~mL}$ of suspension in $9 \mathrm{~mL}$ of APB. Then, $0.1 \mathrm{~mL}$ aliquots of dilution were inoculated into counting plates prepared with agar. Seeding was carried out homogeneously on the surface of the agar. Then, the plates were inverted and incubated at $37{ }^{\circ} \mathrm{C}$ for $48 \mathrm{~h}$. During the count all the colonies that appeared on the plates were taken into account. The microbial load is reported as $\log _{10} \mathrm{CFU}$ per gram of sample. These experiments were performed in triplicate.

\subsection{Color $\left(L^{*}, a^{*}, b^{*}\right)$}

Color coordinates was assessed with a HunterLab colorimeter and a ColorQuest XE sensor, which has the ability to take color measurements by firing a beam of light that emulates the half-day light which corresponds to a color given by a temperature of $6504^{\circ} \mathrm{K}$ and a standard observer located at $10^{\circ}$ of the objects. We used a CIELAB ( $L^{*}, a^{*}$ and $b^{*}$ ) scale that allows the division of the color into three coordinates (Veeck et al., 2013). The samples ( $25 \mathrm{~g}$ of fillets) were taken daily during the storage period $(0,1,2,3,4$, and 5 days) and the registered values were the average of five different records. 


\subsection{Data analysis}

All analysis was measured in triplicate, and the results were expressed as the mean \pm standard deviation (SD). One-way analyses of variance (ANOVA) with Tukey test were performed to determine the statistically significant differences $(p \leq 0.05)$. In order to determine the interactions between groups and measured variables (Texture, WHC, TVB-N, pH, CFU/g, $\mathrm{pH}$ and color), a multifactor analysis of variance was performed. All statistical were performed using SPSS (Statistical Package for the Social Sciences) version 19.0 (SPSS Inc., Chicago, IL, USA) with a significance level of 0.05 (two-sided).

\section{Results and discussion}

\subsection{Texture}

The initial compressive strength was $8.5 \mathrm{~N}$ (Table 1). Statistical analyses indicate that fillet texture is altered by preservation temperature, vacuum pressure and storage time $(p \leq 0.05)$. The lowest texture values were recorded in fillets preserved without packaging. We found significant differences $(p \leq 0.05)$ between wild-caught and farm-raised samples. Compressive strength drastically decreased between the second and fourth day of storage. Although we found no differences in texture values for samples packaged at $35 \mathrm{KPa}$ and $45 \mathrm{KPa}$, we observed significant differences between packed samples and control samples $(p \leq 0.05)$, revealing a protecting effect of vacuum packaging on texture. The lowest texture values reported in this study differ significantly with those reported by León et al. 2019 for cold cryopreserved Yamú fillets. However, these values are still higher than those reported for trout (Oncorhynchus mykiss), after five days of ice preservation (Godiksen et al., 2009). Texture values are also higher than those for Brycon cephalus after 12 hours of storage at $-3{ }^{\circ} \mathrm{C}$ (Suárez-Mahecha et al., 2007).

The loss of texture in the Yamú fillets studied may be the effect of different factors. The first is the degradation caused by free radicals on myofibrillar proteins, which constitute the muscle of the fish. The decomposition or alteration of its chemical structure causes the muscle to exhibit less resistance to the probes used in texturometers (Piedrahíta-Márquez et al., 2019). On the other hand, failures in connective tissue could occur due to the effect of freezing, especially in preserved fillets without vacuum packing. Treatments in which, greater intracellular and intercellular generation of ice crystals that could damage the muscular structure releasing enzymes (collagenases) that destroy the connective tissue, specially the activity of cathepsins over both collagen and myofibrillar proteins (Hultmann \& Rustad, 2002; Hassoun \& Karoui, 2016). This type of enzymes has significantly higher degradation of this proteins at $\mathrm{pH} 6$ than at $\mathrm{pH} 7$ (Qin et al., 2016), pH values that coinciding with pH Yamú samples reported in this work below. Finally, the bacterial load in the sample may also have affected the texture properties since the microorganism present are capable of degrading the meat. Vacuum packaging limits but not kill microorganisms which could cause the degradation of proteins due to metabolite production (Wang et al., 2014). This effect is demonstrated with the less production of TVB-N on fillets with a vacuum preservation package and how this parameter highly increased with conservation time. 
Table 1. Shows the means of Texture $(\mathrm{N}) \pm$ the standard deviation of each treatment.

\begin{tabular}{|c|c|c|c|c|c|}
\hline \multirow{2}{*}{ Temperature } & \multirow{2}{*}{ Time } & \multirow{2}{*}{ Origen } & \multicolumn{3}{|c|}{ Package } \\
\hline & & & Control & $35 \mathrm{kPa}$ & $45 \mathrm{kPa}$ \\
\hline \multirow{10}{*}{$\mathbf{0}^{\circ} \mathbf{C}$} & \multirow{2}{*}{ D1 } & River & $7.80 \pm 0.18$ & $7.72 \pm 0.32$ & $7.40 \pm 0.30$ \\
\hline & & Farm & $8.57 \pm 0.18$ & $8.93 \pm 0.87$ & $8.47 \pm 0.73$ \\
\hline & \multirow{2}{*}{ D2 } & River & $5.46 \pm 0.25$ & $5.72 \pm 0.15$ & $6.40 \pm 0.25$ \\
\hline & & Farm & $5.25 \pm 0.27$ & $8.67 \pm 0.26$ & $8.19 \pm 0.21$ \\
\hline & \multirow{2}{*}{ D3 } & River & $3.23 \pm 0.17$ & $3.36 \pm 0.12$ & $4.27 \pm 0.20$ \\
\hline & & Farm & $3.34 \pm 0.14$ & $7.01 \pm 1.22$ & $6.52 \pm 0.83$ \\
\hline & \multirow{2}{*}{ D4 } & River & $1.83 \pm 0.87$ & $2.05 \pm 0.50$ & $3.08 \pm 0.55$ \\
\hline & & Farm & $1.44 \pm 0.40$ & $5.06 \pm 0.35$ & $4.59 \pm 0.10$ \\
\hline & \multirow{2}{*}{ D5 } & River & $1.99 \pm 0.33$ & $1.86 \pm 0.42$ & $2.77 \pm 0.45$ \\
\hline & & Farm & $1.42 \pm 0.04$ & $5.06 \pm 0.35$ & $4.35 \pm 0.62$ \\
\hline \multirow{10}{*}{$-18^{\circ} \mathrm{C}$} & \multirow{2}{*}{ D1 } & River & $7.36 \pm 0.53$ & $7.75 \pm 0.60$ & $8.01 \pm 0.10$ \\
\hline & & Farm & $8.73 \pm 0.09$ & $8.58 \pm 0.37$ & $8.94 \pm 0.30$ \\
\hline & \multirow{2}{*}{ D2 } & River & $5.94 \pm 0.50$ & $7.42 \pm 0.5$ & $7.81 \pm 0.50$ \\
\hline & & Farm & $6.21 \pm 0.55$ & $8.06 \pm 0.53$ & $8.33 \pm 0.01$ \\
\hline & \multirow{2}{*}{ D3 } & River & $3.59 \pm 0.48$ & $5.45 \pm 0.58$ & $5.79 \pm 0.53$ \\
\hline & & Farm & $4.1 \pm 0.64$ & $7.34 \pm 0.71$ & $7.92 \pm 1.21$ \\
\hline & \multirow{2}{*}{ D4 } & River & $2.55 \pm 0.78$ & $3.67 \pm 0.52$ & $4.38 \pm 0.73$ \\
\hline & & Farm & $2.92 \pm 0.15$ & $5.77 \pm 0.22$ & $6.20 \pm 0.37$ \\
\hline & \multirow{2}{*}{ D5 } & River & $2.64 \pm 0.49$ & $3.88 \pm 0.24$ & $4.09 \pm 0.20$ \\
\hline & & Farm & $2.72 \pm 0.17$ & $5.46 \pm 0.30$ & $5.90 \pm 1.07$ \\
\hline
\end{tabular}

\subsection{Water Holding Capacity (WHC \%)}

As shown by previous work, Yamú is a fish species that, once subjected to cold preservation, is affected by proteolytic processes that result in a loss of technological properties (Castañeda et al., 2016; León Ramírez et al., 2019). During this experiment, WHC of observed Yamú fish fillets was also affected during cold preservation of samples. Values for this variable ranged between $25.25 \%$ and $68.80 \%$ (Table 2), indicating a large decrease of WHC during the first $24 \mathrm{~h}$ of storage. Data analysis shows a significant effect of all factors and their interactions on WHC $(p \leq 0.05)$. This decrease of WHC can be attributed to the damage of cell membranes and subsequent loss of function and capacity of rehydration. In general terms, Yamú fillets from fish exhibited lower WHC values. However, these values are still lower than those reported by SánchezAlonso et al. (2012) in M. merluccius fillets. The samples most affected by cold preservation were those preserved without packaging and at $0{ }^{\circ} \mathrm{C}$, reflecting the cryoprotectant effect of vacuum on fillets, helping to increase their shelf life.

This loss of WHC is totally related to changes on the protein-water interaction, produced by the alteration of secondary structure of proteins (Sánchez-Alonso et al., 2012). We suggest, that this alteration and its consequently with texture and $\mathrm{pH}$ results, indicate that the effect of endogenous enzymes could be the responsible of alteration of Yamú fillets even under refrigeration and vacuum conditions. 
Table 2. Shows the means of water holding capacity (WHC \%), \pm the standard deviation of each treatment.

\begin{tabular}{|c|c|c|c|c|c|}
\hline \multirow{2}{*}{ Temperature } & \multirow{2}{*}{ Time } & \multirow{2}{*}{ Origen } & \multicolumn{3}{|c|}{ Package } \\
\hline & & & Control & $35 \mathrm{kPa}$ & $45 \mathrm{kPa}$ \\
\hline \multirow{10}{*}{$0^{\circ} \mathrm{C}$} & \multirow{2}{*}{ D1 } & River & $66.27 \pm 0.86$ & $68.17 \pm 1.60$ & $68.17 \pm 0.90$ \\
\hline & & Farm & $65.88 \pm 0.79$ & $66.17 \pm 1.89$ & $66.11 \pm 0.20$ \\
\hline & \multirow{2}{*}{ D2 } & River & $41.35 \pm 1.26$ & $49.84 \pm 1.97$ & $49.52 \pm 1.45$ \\
\hline & & Farm & $42.46 \pm 1.57$ & $47.52 \pm 1.42$ & $47.00 \pm 1.22$ \\
\hline & \multirow{2}{*}{ D3 } & River & $38.29 \pm 1.36$ & $46.37 \pm 1.96$ & $46.89 \pm 2.19$ \\
\hline & & Farm & $38.52 \pm 0.24$ & $44.69 \pm 0.75$ & $44.83 \pm 1.33$ \\
\hline & \multirow{2}{*}{ D4 } & River & $30.45 \pm 1.04$ & $37.87 \pm 2.29$ & $37.94 \pm 2.46$ \\
\hline & & Farm & $30.38 \pm 1.47$ & $35.26 \pm 0.64$ & $35.87 \pm 1.24$ \\
\hline & \multirow{2}{*}{ D5 } & River & $19.29 \pm 0.05$ & $27.24 \pm 2.85$ & $27.56 \pm 3.02$ \\
\hline & & Farm & $26.54 \pm 2.04$ & $26.65 \pm 0.78$ & $25.71 \pm 0.96$ \\
\hline \multirow{10}{*}{$-18^{\circ} \mathrm{C}$} & \multirow{2}{*}{ D1 } & River & $65.89 \pm 0.95$ & $68.81 \pm 1.93$ & $68.36 \pm 1.29$ \\
\hline & & Farm & $64.29 \pm 4.13$ & $68.81 \pm 1.93$ & $68.36 \pm 1.30$ \\
\hline & \multirow{2}{*}{ D2 } & River & $46.77 \pm 1.13$ & $50.63 \pm 2.08$ & $49.5 \pm 2.19$ \\
\hline & & Farm & $45.40 \pm 2.56$ & $50.63 \pm 1.40$ & $49.50 \pm 0.19$ \\
\hline & \multirow{2}{*}{ D3 } & River & $43.95 \pm 0.14$ & $47.32 \pm 1.79$ & $46.95 \pm 1.91$ \\
\hline & & Farm & $41.66 \pm 0.40$ & $47.32 \pm 1.79$ & $46.95 \pm 1.91$ \\
\hline & \multirow{2}{*}{ D4 } & River & $35.74 \pm 0.74$ & $41.01 \pm 3.76$ & $42.01 \pm 2.63$ \\
\hline & & Farm & $33.53 \pm 2.52$ & $39.01 \pm 1.12$ & $38.01 \pm 2.16$ \\
\hline & \multirow{2}{*}{ D5 } & River & $24.79 \pm 1.59$ & $34.84 \pm 1.71$ & $35.67 \pm 0.87$ \\
\hline & & Farm & $25.25 \pm 1.49$ & $27.84 \pm 0.65$ & $27.67 \pm 0.95$ \\
\hline
\end{tabular}

\subsection{TVB-N analysis in Yamú fillets}

TVB-N was influenced by all four factors (fish source, temperature, packaging, and storage time), as well as by the interaction of temperature and storage time $(p \leq 0.05)$. Samples preserved without vacuum exhibited significantly higher TVB-N values than those that were vaccum-preserved, indicating that pressure package reduces the protein degradation, caused by endogen proteolytic enzymes. These results are higher than reported by Kachele et al. (2017) for fillets of Hypophthalmichthys molitrix preserved at $4{ }^{\circ} \mathrm{C} ; 50 \mathrm{kPa}$ and $35 \mathrm{kPa}$, demonstrating that Yamú fillets are most susceptible of enzymatic action even on cold storage.

Volatile base concentration (TVB-N) is an indicator of decay in fish meat. These nitrogen bases, mostly comprised by triethylamine, diethylamine and ammonia, result from the degradation of protein and non-protein nitrogen by endogenous enzymes and spoilage bacteria (Fan et al., 2009). Initial TVB-N concentrations in fresh-caught, freshwater fish range between 5 and $20 \mathrm{mg} \mathrm{N} / 100 \mathrm{~g}$ (Boran \& Köse, 2007; Méndez et al., 2017). In this study, TVB-N reached high values $(12.93 \pm 3.01)$ after two days of cold storage (Table 3$)$. These TVB-N values were higher than those reported for Sparus aurata and merluccius merluccius (Kyrana et al., 1997; Vázquez et al., 2018), indicating that ammonia levels were already elevated after two days of cold storage surpassing of Colombian regulation limit (Colombia, 2012). The increase of TVB-N is probably due to the activity of endogenous enzymes, spoilage bacteria and the subsequently increase of microbial degradation products including ammonia, primary, secondary, and tertiary amines (Kakaei \& Shahbazi, 2016). Specifically, in this work a similar pattern could be observed between the increase in the production of TVB-N and in the colony-forming units, which allows researchers to infer that the formation of nitrogen compounds can be caused by enzymes produced by the microbial load, which increased with storage time. 
Table 3. Shows the means of total nitrogenous volatile bases (TVB-N mg N/100 g) \pm the standard deviation of each treatment.

\begin{tabular}{|c|c|c|c|c|c|}
\hline \multirow{2}{*}{ Temperature } & \multirow{2}{*}{ Time } & \multirow{2}{*}{ Origen } & \multicolumn{3}{|c|}{ Package } \\
\hline & & & Control & $35 \mathrm{kPa}$ & $45 \mathrm{kPa}$ \\
\hline \multirow{10}{*}{$\mathbf{0}^{\circ} \mathrm{C}$} & \multirow{2}{*}{ D1 } & River & $9.50 \pm 0.27$ & $7.94 \pm 0.68$ & $11.99 \pm 1.41$ \\
\hline & & Farm & $11.87 \pm 0.73$ & $6.98 \pm 0.89$ & $12.62 \pm 0.36$ \\
\hline & \multirow{2}{*}{ D2 } & River & $43.15 \pm 5.73$ & $39.49 \pm 1.48$ & $37.94 \pm 1.81$ \\
\hline & & Farm & $43.38 \pm 1.64$ & $35.93 \pm 1.35$ & $35.87 \pm 2.04$ \\
\hline & \multirow{2}{*}{ D3 } & River & $53.12 \pm 2.11$ & $47.22 \pm 2.55$ & $46.89 \pm 1.41$ \\
\hline & & Farm & $51.38 \pm 3.98$ & $46.33 \pm 0.78$ & $44.83 \pm 1.10$ \\
\hline & \multirow{2}{*}{ D4 } & River & $54.07 \pm 2.24$ & $51.47 \pm 1.83$ & $49.52 \pm 1.17$ \\
\hline & & Farm & $52.51 \pm 1.37$ & $48.31 \pm 0.38$ & $47 \pm 3.34$ \\
\hline & \multirow{2}{*}{ D5 } & River & $73.45 \pm 0.73$ & $69.96 \pm 1.71$ & $68.17 \pm 1.69$ \\
\hline & & Farm & $71.53 \pm 2.10$ & $69.13 \pm 2.63$ & $66.11 \pm 5.60$ \\
\hline \multirow{10}{*}{$-18^{\circ} \mathrm{C}$} & \multirow{2}{*}{ D1 } & River & $16.33 \pm 2.38$ & $10.69 \pm 0.78$ & $7.76 \pm 0.34$ \\
\hline & & Farm & $6.97 \pm 0.45$ & $7.79 \pm 0.07$ & $6.97 \pm 0.45$ \\
\hline & \multirow{2}{*}{ D2 } & River & $40.86 \pm 1.51$ & $41.41 \pm 1.04$ & $38.01 \pm 0.74$ \\
\hline & & Farm & $38.01 \pm 3.58$ & $40.44 \pm 2.16$ & $38.01 \pm 3.58$ \\
\hline & \multirow{2}{*}{ D3 } & River & $53.24 \pm 1.74$ & $48.93 \pm 0.57$ & $46.95 \pm 1.29$ \\
\hline & & Farm & $46.95 \pm 1.69$ & $48.78 \pm 2.0$ & $46.95 \pm 1.69$ \\
\hline & \multirow{2}{*}{ D4 } & River & $54.42 \pm 2.83$ & $52.66 \pm 1.47$ & $49.50 \pm 1.90$ \\
\hline & & Farm & $49.5 \pm 1.46$ & $51.47 \pm 2.38$ & $49.5 \pm 1.46$ \\
\hline & \multirow{2}{*}{ D5 } & River & $73.96 \pm 2.52$ & $70.89 \pm 2.62$ & $68.36 \pm 1.37$ \\
\hline & & Farm & $68.36 \pm 2.38$ & $71.06 \pm 3.13$ & $68.36 \pm 2.38$ \\
\hline
\end{tabular}

\section{$3.4 \mathrm{pH}$}

The Yamú fillets $\mathrm{pH}$ was affected by the origin of the fishes and the package (Table 4). Initial fish fillets $\mathrm{pH}$ ranges between 6.0 and 7.0, depending on the species, diet, season, and muscle type, as well as the level of activity or stress during capture (He \& Xiao, 2016). It is evident the cryoprotective effect that caused the packing of the fillets, regardless of the pressure used (Table 4). The $\mathrm{pH}$ increase on fillets stored without pressure package could be attributed to the build-up of alkaline compounds produced by bacterial growth, such as ammonia and triethylamine (Li et al., 2012a, 2017). This is consistent with results obtained for microbiological analysis showed before. Other significant effect over $\mathrm{pH}$ values was the origin of the fishes. These phenomena could be related with the variations on the diet between wild and cultured fishes $(\mathrm{He} \&$ Xiao, 2016). Initial decrease of $\mathrm{pH}$ can be explained to an accumulation of lactic acid produced by glycolysis. Similarly, a low pH is directly related to the loss of texture (Kiessling et al., 2004) due to the weakening of connective tissue and protein denaturation.

Table 4. Shows the means of $\mathrm{pH} \pm$ the standard deviation of each of the treatments.

\begin{tabular}{|c|c|c|c|c|c|}
\hline \multirow{2}{*}{ Temperature } & \multirow{2}{*}{ Time } & \multirow{2}{*}{ Origen } & \multicolumn{3}{|c|}{ Package } \\
\hline & & & Control & $35 \mathrm{kPa}$ & $45 \mathrm{kPa}$ \\
\hline \multirow{10}{*}{$\mathbf{0}^{\circ} \mathrm{C}$} & \multirow{2}{*}{ D1 } & River & $6.52 \pm 0.09$ & $6.51 \pm 0.05$ & $6.66 \pm 0.50$ \\
\hline & & Farm & $7.02 \pm 0.16$ & $6.28 \pm 0.11$ & $6.37 \pm 0.31$ \\
\hline & \multirow{2}{*}{ D2 } & River & $6.47 \pm 0.16$ & $6.40 \pm 0.02$ & $6.38 \pm 0.16$ \\
\hline & & Farm & $6.97 \pm 0.2$ & $6.52 \pm 0.46$ & $6.76 \pm 0.26$ \\
\hline & \multirow{2}{*}{ D3 } & River & $6.46 \pm 0.08$ & $6.47 \pm 0.17$ & $6.25 \pm 0.46$ \\
\hline & & Farm & $6.91 \pm 0.17$ & $6.71 \pm 0.25$ & $6.41 \pm 0.37$ \\
\hline & \multirow{2}{*}{ D4 } & River & $6.58 \pm 0.21$ & $6.70 \pm 0.16$ & $6.44 \pm 0.14$ \\
\hline & & Farm & $7.03 \pm 0.18$ & $6.62 \pm 0.29$ & $6.35 \pm 0.33$ \\
\hline & \multirow{2}{*}{ D5 } & River & $6.45 \pm 0.12$ & $6.40 \pm 0.27$ & $6.58 \pm 0.38$ \\
\hline & & Farm & $7.04 \pm 0.03$ & $6.28 \pm 0.2$ & $6.43 \pm 0.04$ \\
\hline
\end{tabular}


Table 4. Continued..

\begin{tabular}{|c|c|c|c|c|c|}
\hline \multirow{2}{*}{ Temperature } & \multirow{2}{*}{ Time } & \multirow{2}{*}{ Origen } & \multicolumn{3}{|c|}{ Package } \\
\hline & & & Control & $35 \mathrm{kPa}$ & $45 \mathrm{kPa}$ \\
\hline \multirow{10}{*}{$-18^{\circ} \mathrm{C}$} & \multirow{2}{*}{ D1 } & River & $6.55 \pm 0.07$ & $6.24 \pm 0.15$ & $6.67 \pm 0.34$ \\
\hline & & Farm & $6.55 \pm 0.07$ & $6.55 \pm 0.2$ & $6.65 \pm 0.23$ \\
\hline & \multirow{2}{*}{ D2 } & River & $6.56 \pm 0.03$ & $6.40 \pm 0.35$ & $6.69 \pm 0.22$ \\
\hline & & Farm & $6.56 \pm 0.05$ & $6.44 \pm 0.41$ & $6.54 \pm 0.31$ \\
\hline & \multirow{2}{*}{ D3 } & River & $6.56 \pm 0.03$ & $6.61 \pm 0.21$ & $6.50 \pm 0.41$ \\
\hline & & Farm & $6.56 \pm 0.06$ & $6.58 \pm 0.34$ & $6.66 \pm 0.29$ \\
\hline & \multirow{2}{*}{ D4 } & River & $6.60 \pm 0.02$ & $6.50 \pm 0.07$ & $6.68 \pm 0.46$ \\
\hline & & Farm & $6.6 \pm 0.05$ & $6.61 \pm 0.31$ & $6.54 \pm 0.4$ \\
\hline & \multirow{2}{*}{ D5 } & River & $6.53 \pm 0.05$ & $6.59 \pm 0.25$ & $6.24 \pm 0.22$ \\
\hline & & Farm & $6.53 \pm 0.14$ & $6.75 \pm 0.24$ & $6.51 \pm 0.45$ \\
\hline
\end{tabular}

\subsection{Microbiological analysis}

CFU/g in Yamú fillets ranged between 2.72 and 9.74 (Figure 1a and 1b), similar to previously reported values (Wang et al., 2014). Microbial load of fish may be influenced by factors such as species, water temperature, and transport conditions. Multifactorial analysis reveals that variation in CFU is caused by the individual effects of storage temperature $\left(0^{\circ} \mathrm{C},-18^{\circ} \mathrm{C}\right)$, packaging type (WPV, $\left.35 \mathrm{kPa}, 45 \mathrm{kPa}\right)$ and storage time (D1, D2, D3, D4, D5), as well as the interaction between storage temperature and packaging type $(p \leq 0.05)$. Initial CFU values were low (2.11) indicating that muscle of fish used in this study was sterile regardless of the origin of them and a consistent trend towards CFU increase with time was observed, suggesting that the bacterial quantified during investigation process, could be the result of contamination bacterial from the fish surface or viscera or by human handling and storage conditions. The samples that surpassed the maximum CFU level (7.0 log CFU/g) allowed for continental water fish were those stored without packaging (control group). These results suggested that vacuum package is an effective method to control bacterial growth on fish fillets, even on bacterial colonies that can present growing during cold storage.

After three days of storage, the colonies of bacterial present in samples from river conserved under pressure not presented differences $(p \leq 0.05)$, similar phenomena presented samples by farm, but this similarity was evident since day one of storage. Altogether, the results highlight the effect of vacuum packaging to slow down colony formation in samples, increasing the shelf life of Yamú, this can be attributed to the decrease in oxygen levels in vacuum-packaged samples ( $\mathrm{Li}$ et al., 2012b). These results allow inferring an approximate shelf life of 4 days for cold-preserved, vacuum-packaged Yamú fillets, without health risk to the consumer. 


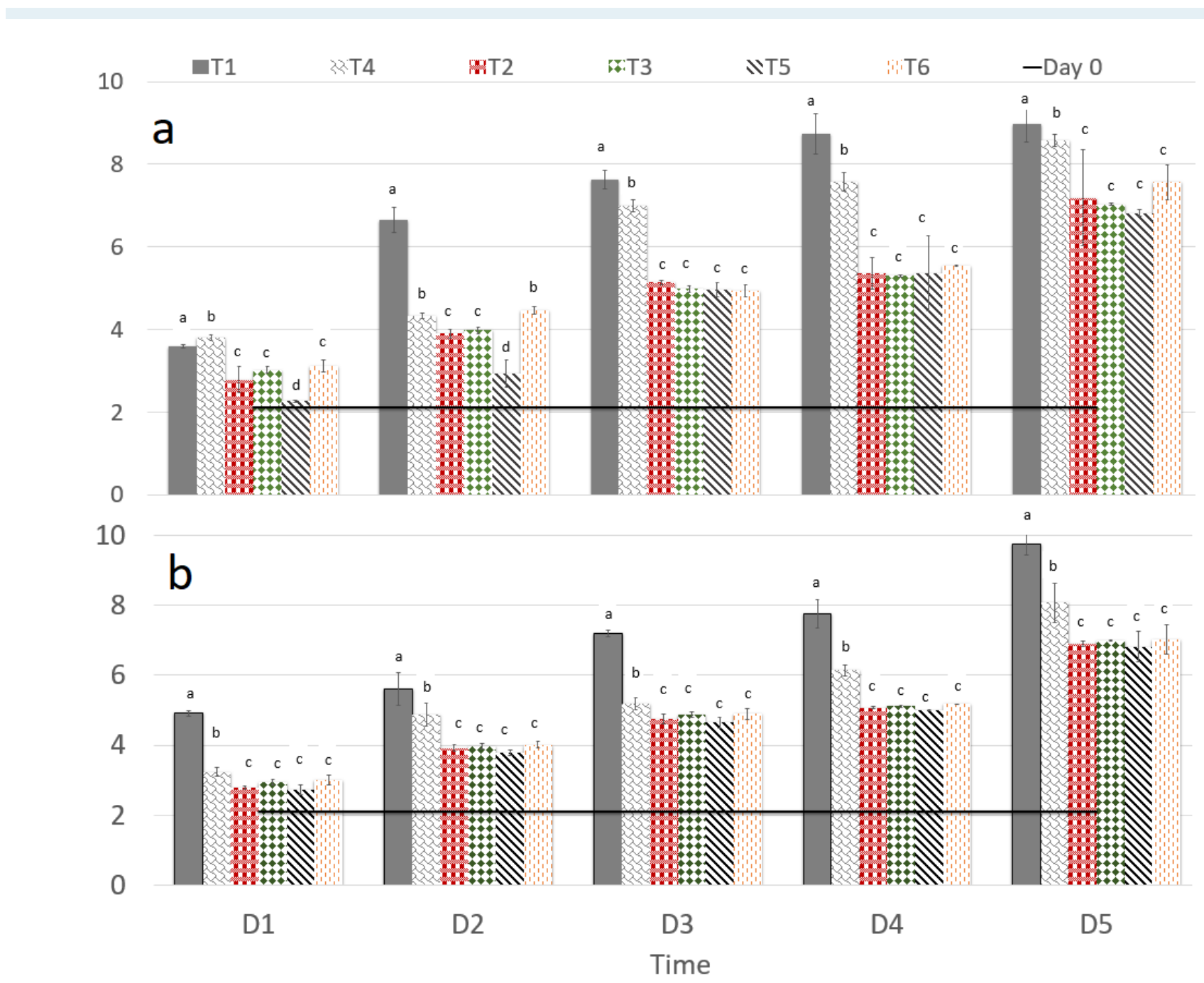

Figure 1. Mean of UFC/g, for each treatment $\left(\mathrm{T} 1: 0{ }^{\circ} \mathrm{C}\right.$ Control; $\mathrm{T} 2: 0{ }^{\circ} \mathrm{C} 35 \mathrm{kPa} ; \mathrm{T} 3: 0{ }^{\circ} \mathrm{C} 45 \mathrm{kPa}$; $\mathrm{T} 4:-18{ }^{\circ} \mathrm{C}$ Control; T5: $-18{ }^{\circ} \mathrm{C} 35 \mathrm{kPa}$; T6: $-18{ }^{\circ} \mathrm{C} 45 \mathrm{kPa}$ ). (a) shows the values of samples from the river; (b) shows the values of samples from farm. Black line refers to the value of $\mathrm{CFU} / \mathrm{g}$ on day 0 . Means with different small letters in the same day represent significant difference at $p \leq 0.05$. Errors bars denotes standard deviation.

\subsection{Color}

Figure 2 shows the results of color analysis for coordinates $L^{*}, a^{*}, b^{*}$, in Yamú fillets under different conditions of vacuum and temperature. Values for coordinate $L^{*}$ were affected by type of packaging and storage time $(p \leq 0.05)$. Values samples vacuumed and packed at $45 \mathrm{kPa}$ and $35 \mathrm{kPa}$ were significantly $(p \leq 0.05)$ higher than control samples during the entire storage time. The lowest values for this coordinate were obtained from fillets stored without packaging. These values were greater than values for coordinate $\mathrm{L}^{*}$ reported for silver carp stored under different vacuum levels at $4{ }^{\circ} \mathrm{C}$ (Kachele et al., 2017), and for fillets of silver carp conserved at $4{ }^{\circ} \mathrm{C}$ with extracts of clove and grapes (Shi et al., 2014). In contrast, values founding in this work are more related with data reported by Aubourg et al. (2013) for fillets of Scombre scombrus under high pressure. The mechanisms of those changes are not entirely clear. However, Carlez et al. (1995) suggested that an increase in $L^{*}$ value could be denaturation of proteins when pressures of 200-300 MPa are applied for $10 \mathrm{~min}$. This theory, explains why L* values for Yamú fillets did not showed a drastically changes, since the pressures used in this investigation were significantly lower than those reported as cause of protein denaturation. However, our additional analyzes (texture, WHC and TVB-N) and Kamani et al. (2017) allowed to infer protein degradation caused by microorganism or endogenous enzymes, could cause an alteration over $\mathrm{L}^{*}$ coordinate. 


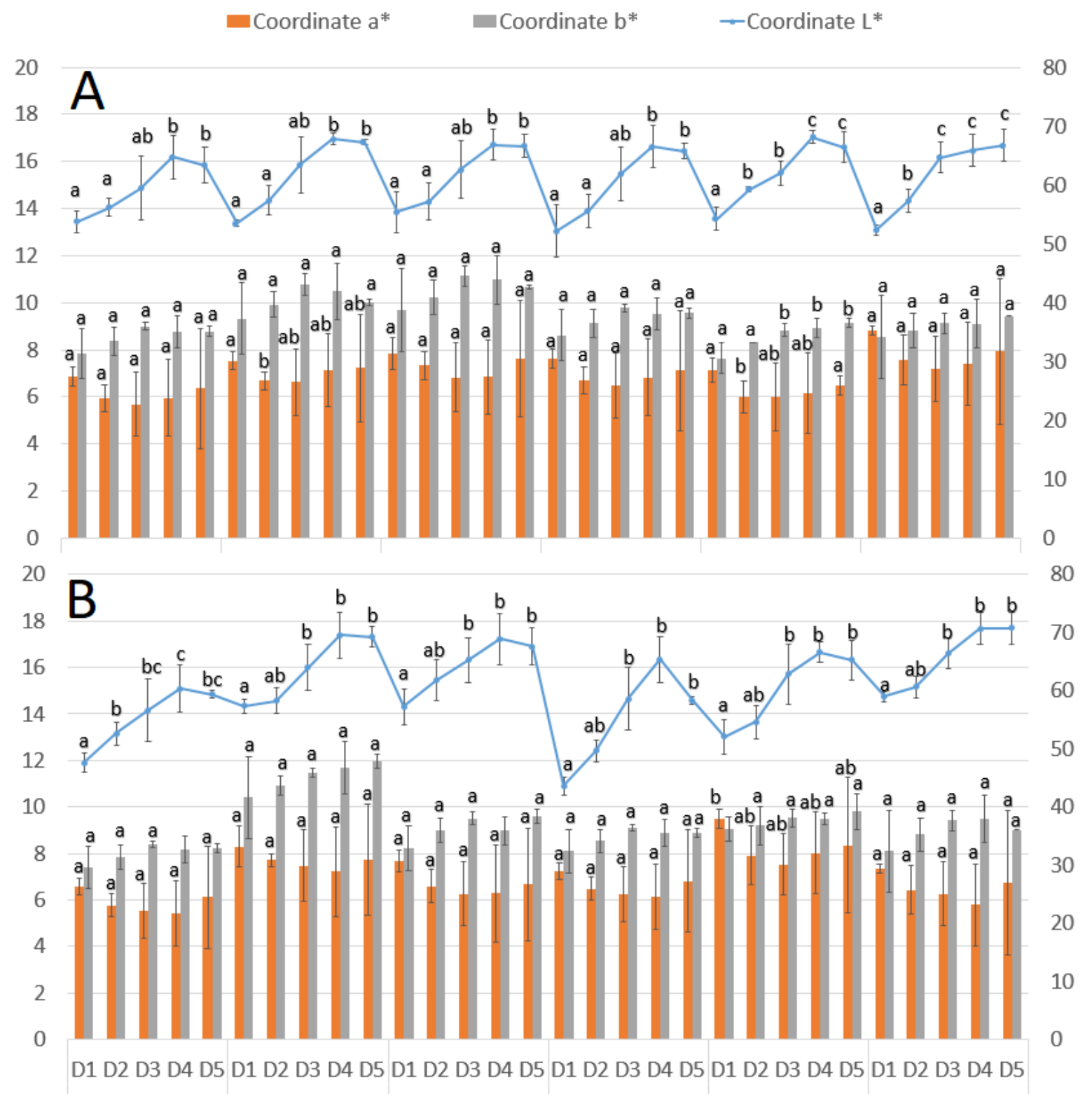

T1

$\mathrm{T} 2$

T3

T4

T5

T6

Figure 2. Mean \pm standard deviation of the colorimetric coordinates $\mathrm{L}^{*}, \mathrm{a} *$ and $\mathrm{b} *$, for each treatment $\left(\mathrm{T} 1: 0{ }^{\circ} \mathrm{C}\right.$ Control; T2: $0{ }^{\circ} \mathrm{C} 35 \mathrm{kPa}$; T3: $0{ }^{\circ} \mathrm{C} 45 \mathrm{kPa}$; T4: $-18{ }^{\circ} \mathrm{C}$ Control; $\mathrm{T} 5:-18{ }^{\circ} \mathrm{C} 35 \mathrm{kPa}$; T6: $-18{ }^{\circ} \mathrm{C} 45 \mathrm{kPa}$ ). (A) shows the values of samples from the river; (B) shows the values of samples from farm. Right axis represent scale for $\mathrm{L}^{*}$ coordinate (line). Means with different small letters in the same day represent significant difference at $p<0.05$. Errors bars denotes standard deviation.

Values for coordinate $\mathrm{a}^{*}$ were affected by package type and storage time, as well by the interactions of fish origin (wild-caught or fish-farmed) with temperature and packaging $(p<0.05)$. The highest values were recorded in samples stored at $-18^{\circ} \mathrm{C}$, particularly on samples stored at $35 \mathrm{kPa}(8.26 \pm 1.62)$. Samples from farm-raised animals and preserved without packaging exhibited the lowest values in this coordinate (5.88 \pm 1.18 ), in agreement with reported values for silver carp (Hypophthalmichthys molitrix) refrigerated with natural antioxidants (Shi et al., 2014). The highest values for $\mathrm{a}^{*}$ were recorded in samples stored at $-18{ }^{\circ} \mathrm{C}$, particularly on samples stored at $35 \mathrm{kPa}(8.26 \pm 1.62)$. Samples from farm-raised animals, and preserved without packaging exhibited the lowest values in this coordinate $(5.88 \pm 1.18)$, corroborating with reported values for silver carp (Hypophthalmichthys molitrix) refrigerated with natural antioxidants (Shi et al., 2014). Nevertheless, we observed a different behavior of this coordinate values in comparison with values reported 
by Erkan et al. (2011), who suggests a loss of redness intensity when fillets are subjected to high conservation pressures; these phenomena suggest a stability of the red meat color over the old storage.

As with $\mathrm{L}^{*}$ and $\mathrm{a}^{*}$ coordinates, the low values reported for coordinate $\mathrm{b}^{*}$ were found in samples from farm-raised fish, stored at $-18{ }^{\circ} \mathrm{C}$, packaged at $45 \mathrm{kPa}(8.97 \pm 0.81)$, as well as in samples from farm-raised fish and preserved without packaging $(7.99 \pm 0.59)$. Values for this coordinate were gradually increasing until the third day of storage, after which no we found significant differences $(p \leq 0.05)$.

Color variations reported in this study can be attributed to protein or lipid oxidation, both processes previously reported as causes of color loss in meat (Veeck et al., 2013; Ferreira et al., 2017). The increase in $b^{*}$ value was possibly associated with the increase in TBARS value. $L^{*} a^{*}$ and $b^{*}$ values increased significantly indicating an increase in lightness, yellow and a lesser extend redness of fillets stored during experiment.

\section{Conclusions}

Our results allowed to demonstrate a cryoprotective effect of the combination of pressure and storage temperature $\left(35 \mathrm{kPa}\right.$ and $\left.-18{ }^{\circ} \mathrm{C}\right)$ on Yamú fillets, presenting less loss in the quality attributes evaluated. In addition, we provide additional knowledge about the phenomenon that causes the loss of quality in Yamú meat, finding a direct relationship between the loss of texture and the increase in microbial counts as in the concentration of nitrogenated bases content. The relationship that can be explained by presence of endogenous microorganisms and/or enzymes that present proteolytic capacity. Therefore, to extend the shelf life and delay the deterioration of Yamú fillets during cold storage, it is necessary to identify and inhibit enzymes and microorganisms present in the muscle of this species.

\section{References}

Anderson, J., Asche, F., Garlock, T., \& Chu, J. (2017). Aquaculture: Its role in the future of food. In A. Schmitz, P. L. Kennedy \& T. G. Schmitz (Eds.), World agricultural resources and food security (Frontiers of Economics and Globalization, Vol. 17, pp. 159173). Bingley: Emerald.

Ando, M., Nishiyabu, A., Tsukamasa, Y., \& Makinodan, Y. (1999). Post-mortem softening of fish muscle during chilled storage as affected by bleeding. Journal of Food Science, 64(3), 423-428. http://dx.doi.org/10.1111/j.1365-2621.1999.tb15056.x

Arias, J. (2006). Estado actual del conocimiento sobre el Yamú, Brycon Amazonicus. Revista Colombiana de Ciencias Pecuarias, 19(2), 9.

Aubourg, S. P., Torres, J. A., Saraiva, J. A., Guerra-Rodríguez, E., \& Vázquez, M. (2013). Effect of high-pressure treatments applied before freezing and frozen storage on the functional and sensory properties of Atlantic mackerel (Scomber scombrus). Lebensmittel-Wissenschaft + Technologie, 53(1), 100-106. http://dx.doi.org/10.1016/j.lwt.2013.01.028

Barros, I. B. A., Villacorta-Correa, M. A., \& Carvalho, T. B. (2019). Stocking density and water temperature as modulators of aggressiveness, survival and zootechnical performance in matrinxã larvae, Brycon amazonicus. Aquaculture, 502, 378-383. http://dx.doi.org/10.1016/j.aquaculture.2018.12.070

Boran, M., \& Köse, S. (2007). Storage properties of three types of fried whiting balls at refrigerated temperatures. Turkish Journal of Fisheries and Aquatic Sciences, 7(1), 65-70.

Carlez, A., Veciana-Nogues, T., \& Cheftel, J. C. (1995). Changes in colour and myoglobin of minced beef meat due to high pressure processing. Lebensmittel-Wissenschaft + Technologie, 28(5), 528-538. http://dx.doi.org/10.1006/fstl.1995.0088

Castañeda, D., Lozano, J. M., \& Suárez, H. (2016). Microstructural changes and the effect on myofibril proteins in Yamú (Brycon amazonicus) fish meat during cold storage. Agronomia Colombiana, 34(3), 403-414. http://dx.doi.org/10.15446/agron.colomb.v34n3.61316

Chéret, R., Delbarre-Ladrat, C., Lamballerie-Anton, M. D., \& Verrez-Bagnis, V. (2007). Calpain and cathepsin activities in post mortem fish and meat muscles. Food Chemistry, 101(4), 1474-1479. http://dx.doi.org/10.1016/j.foodchem.2006.04.023

Colombia. Ministry of Health and Social Protection. (2012, january 31). Por la cual se modifica parcialmente la Resolución número 776 de 2008 (Resolucion 122 de 2012 (enero 26)). Diario Oficial, Bogotá. Recuperado el 22 de enero de 2019, de https://www.minsalud.gov.co/sites/rid/Lists/BibliotecaDigital/RIDE/DE/DIJ/resolucion-0122-de-2012.pdf

Erkan, N., Üretener, G., Alpas, H., Selçuk, A., Özden, Ö., \& Buzrul, S. (2011). Effect of high hydrostatic pressure (HHP) treatment on physicochemical properties of horse mackerel (Trachurus trachurus). Food and Bioprocess Technology, 4(7), 1322-1329. http://dx.doi.org/10.1007/s11947-010-0415-4

European Union. (1991, september 24). Council Directive 91/493/EEC of 22 July 1991 laying down the health conditions for the production and the placing on the market of fishery products. Official Journal of the European Communities, Bruxelas. 
Fan, W., Sun, J., Chen, Y., Quu, J., Zhang, Y., \& Chi, Y. (2009). Effects of chitosan coating on quality and shelf life of silver carp during frozen storage. Food Chemistry, 115(1), 66-70. http://dx.doi.org/10.1016/j.foodchem.2008.11.060

Ferreira, L. F., Daniel, A. P., Piccolo, J., Klein, B., Ruviaro, A. R., \& Emanuelli, T. (2017). Infusão de aloysia triphylla: Efeitos opostos em um teste de atividade antioxidante in vitro e na estabilidade oxidativa de patês de pescado refrigerados. Boletim do Centro de Pesquisa e Processamento de Alimentos, 34(2), 1-12. http://dx.doi.org/10.5380/cep.v34i2.53180

Godiksen, H., Morzel, M., Hyldig, G., \& Jessen, F. (2009). Contribution of cathepsins B, L and D to muscle protein profiles correlated with texture in rainbow trout (Oncorhynchus mykiss). Food Chemistry, 113(4), 889-896. http://dx.doi.org/10.1016/j.foodchem.2008.08.012

Hashimoto, K., Kobayashi, S., \& Yamashita, M. (2017). Comparison of connective tissue structure and muscle toughness of spotted mackerel Scomber australasicus and Pacific mackerel S. japonicus during chilled and frozen storage. Fisheries Science, 83(1), 133-139. http://dx.doi.org/10.1007/s12562-016-1042-4

Hassoun, A., \& Karoui, R. (2016). Monitoring changes in whiting (Merlangius merlangus) fillets stored under modified atmosphere packaging by front face fluorescence spectroscopy and instrumental techniques. Food Chemistry, 200, 343-353. PMid:26830598. http://dx.doi.org/10.1016/j.foodchem.2016.01.028

He, Q., \& Xiao, K. (2016). The effects of tangerine peel (Citri reticulatae pericarpium) essential oils as glazing layer on freshness preservation of bream (Megalobrama amblycephala) during superchilling storage. Food Control, 69, 339-345. http://dx.doi.org/10.1016/j.foodcont.2016.05.019

Hultmann, L., \& Rustad, T. (2002). Textural changes during iced storage of salmon (Salmo salar) and cod (Gadus morhua). Journal of Aquatic Food Product Technology, 11(3-4), 105-123. http://dx.doi.org/10.1300/J030v11n03_09

Kachele, R., Zhang, M., Gao, Z., \& Adhikari, B. (2017). Effect of vacuum packaging on the shelf-life of silver carp (Hypophthalmichthys molitrix) fillets stored at $4{ }^{\circ} \mathrm{C}$. Lebensmittel-Wissenschaft + Technologie, 80, 163-168. http://dx.doi.org/10.1016/j.Iwt.2017.02.012

Kakaei, S., \& Shahbazi, Y. (2016). Effect of chitosan-gelatin film incorporated with ethanolic red grape seed extract and Ziziphora clinopodioides essential oil on survival of Listeria monocytogenes and chemical, microbial and sensory properties of minced trout fillet. Lebensmittel-Wissenschaft + Technologie, 72, 432-438. http://dx.doi.org/10.1016/j.Iwt.2016.05.021

Kamani, M. H., Safari, O., Mortazavi, S. A., Atash, M. M. S., \& Azghadi, N. M. (2017). Using an image processing based technique and predictive models for assessing lipid oxidation in rainbow trout fillet. Food Bioscience, 19, 42-48. http://dx.doi.org/10.1016/j.fbio.2017.05.005

Kiessling, A., Espe, M., Ruohonen, K., \& Mørkøre, T. (2004). Texture, gaping and colour of fresh and frozen Atlantic salmon flesh as affected by pre-slaughter iso-eugenol or $\mathrm{CO}_{2}$ anaesthesia. Aquaculture, 236(1-4), 645-657.

http://dx.doi.org/10.1016/j.aquaculture.2004.02.030

Kyrana, V. R., Lougovois, V. P., \& Valsamis, D. S. (1997). Assessment of shelf-life of maricultured gilthead sea bream (Sparus aurata) stored in ice. International Journal of Food Science \& Technology, 32(4), 339-347. http://dx.doi.org/10.1046/j.13652621.1997.00408.x

Ladrat, C., Verrez-Bagnis, V., Noël, J., \& Fleurence, J. (2003). In vitro proteolysis of myofibrillar and sarcoplasmic proteins of white muscle of sea bass (Dicentrarchus labrax L.): Effects of cathepsins B, D and L. Food Chemistry, 81(4), 517-525. http://dx.doi.org/10.1016/S0308-8146(02)00481-8

Larsson, T., Koppang, E. O., Espe, M., Terjesen, B. F., Krasnov, A., Moreno, H. M., Rørvik, K.-A., Thomassen, M., \& Mørkøre, T. (2014). Fillet quality and health of Atlantic salmon (Salmo salar L.) fed a diet supplemented with glutamate. Aquaculture, 426 288-295. http://dx.doi.org/10.1016/j.aquaculture.2014.01.034

León Ramírez, J. G., López Vargas, J. H., Lozano Moreno, J. M., \& Muñoz Ramirez, A. P. (2019). Cryoprotective effect of sorbitol on the muscle microstructure of Yamú (Brycon amazonicus) during storage at 2 and- $18{ }^{\circ} \mathrm{C}$. Revista Facultad Nacional de Agronomía, 72(1), 8763-8774. http://dx.doi.org/10.15446/rfnam.v72n1.69182

Li, Q., Zhang, L., Lu, H., Song, S., \& Luo, Y. (2017). Comparison of postmortem changes in ATP-related compounds, protein degradation and endogenous enzyme activity of white muscle and dark muscle from common carp (Cyprinus carpio) stored at 4 ${ }^{\circ} \mathrm{C}$. Lebensmittel-Wissenschaft + Technologie, 78, 317-324. http://dx.doi.org/10.1016/j.Iwt.2016.12.035

$\mathrm{Li}, \mathrm{T}$., Hu, W., Li, J., Zhang, X., Zhu, J., \& Li, X. (2012a). Coating effects of tea polyphenol and rosemary extract combined with chitosan on the storage quality of large yellow croaker (Pseudosciaena crocea). Food Control, 25(1), 101-106. http://dx.doi.org/10.1016/j.foodcont.2011.10.029

Li, T., Li, J., Hu, W., Zhang, X., Li, X., \& Zhao, J. (2012b). Shelf-life extension of crucian carp (Carassius auratus) using natural preservatives during chilled storage. Food Chemistry, 135(1), 140-145. http://dx.doi.org/10.1016/j.foodchem.2012.04.115

Méndez, L., Fidalgo, L. G., Pazos, M., Lavilla, M., Torres, J. A., Saraiva, J. A., Vázquez, M., \& Aubourg, S. P. (2017). Lipid and protein changes related to quality loss in frozen sardine (Sardina pilchardus) previously processed under high-pressure conditions. Food and Bioprocess Technology, 10(2), 296-306. http://dx.doi.org/10.1007/s11947-016-1815-x

Mohan, M., Ramachandran, D., Sankar, T. V., \& Anandan, R. (2007). Influence of pH on the solubility and conformational characteristics of muscle proteins from mullet (Mugilcephalus). Process Biochemistry, 42(7), 1056-1062. http://dx.doi.org/10.1016/j.procbio.2007.04.005

Ocaño-Higuera, V. M., Marquez-Ríos, E., Canizales-Dávila, M., Castillo-Yáñez, F. J., Pacheco-Aguilar, R., Lugo-Sánchez, M. E., García-Orozco, K. D., \& Graciano-Verdugo, A. Z. (2009). Postmortem changes in cazon fish muscle stored on ice. Food Chemistry, 116(4), 933-938. http://dx.doi.org/10.1016/j.foodchem.2009.03.049

Ørnholt-Johansson, G., Gudjónsdóttir, M., Nielsen, M. E., Skytte, J. L., \& Frosch, S. (2017). Analysis of the production of salmon fillet: Prediction of production yield. Journal of Food Engineering, 204, 80-87. http://dx.doi.org/10.1016/j.jfoodeng.2017.02.022 
Piedrahíta-Márquez, D. G., Fuenmayor, C. A., \& Suarez Mahecha, H. (2019). Effect of chitosan-propolis edible coatings on stability of refrigerated cachama (Piaractus brachypomus) vacuum-packed fish fillets. Packaging Technology \& Science, 32(3), 143-153.

Qin, N., Li, D., Hong, H., Zhang, Y., Zhu, B., \& Luo, Y. (2016). Effects of different stunning methods on the flesh quality of grass carp (Ctenopharyngodon idellus) fillets stored at $4{ }^{\circ} \mathrm{C}$. Food Chemistry, 201, 131-138. PMid:26868557. http://dx.doi.org/10.1016/j.foodchem.2016.01.071

Ramezani, Z., Zarei, M., \& Raminnejad, N. (2015). Comparing the effectiveness of chitosan and nanochitosan coatings on the quality of refrigerated silver carp fillets. Food Control, 51, 43-48. http://dx.doi.org/10.1016/j.foodcont.2014.11.015

Ravindran, R., \& Jaiswal, A. K. (2016). Exploitation of food industry waste for high-value products. Trends in Biotechnology, 34(1), 58-69. PMid:26645658. http://dx.doi.org/10.1016/j.tibtech.2015.10.008

Sánchez-Alonso, I., Martinez, I., Sánchez-Valencia, J., \& Careche, M. (2012). Estimation of freezing storage time and quality changes in hake (Merluccius merluccius, L.) by low field NMR. Food Chemistry, 135(3), 1626-1634. PMid:22953903. http://dx.doi.org/10.1016/j.foodchem.2012.06.038

Shi, C., Cui, J., Yin, X., Luo, Y., \& Zhou, Z. (2014). Grape seed and clove bud extracts as natural antioxidants in silver carp (Hypophthalmichthys molitrix) fillets during chilled storage: Effect on lipid and protein oxidation. Food Control, 40, 134-139. http://dx.doi.org/10.1016/j.foodcont.2013.12.001

Simeonidou, S., Govaris, A., \& Vareltzis, K. (1997). Effect of frozen storage on the quality of whole fish and fillets of horse mackerel (Trachurus trachurus) and Mediterranean hake (Merluccius mediterraneus). Zeitschrift für Lebensmitteluntersuchung und-Forschung A, 204(6), 405-410. http://dx.doi.org/10.1007/s002170050102

Soto-Valdez, H., Ezquerra-Brauer, J. M., Márquez-Ríos, E., \& Torres-Arreola, W. (2015). Effect of previous chilling storage on quality loss in frozen $\left(-20^{\circ} \mathrm{C}\right.$ ) sierra (Scomberomorus sierra) muscle packed with a low-density polyethylene film containing butylated hydroxytoluene. Food Science and Technology, 35(1), 202-206. http://dx.doi.org/10.1590/1678-457X.6607

Suárez-Mahecha, H., Beirão, L. H., Francisco, A., Nakaghi, L. S. O., \& Pardo-Carrasco, S. C. (2007). Chilling effect on the postmortem texture of the matrinxã fish muscle Brycon cephalus. Arquivo Brasileiro de Medicina Veterinária e Zootecnia, 59(4), 1067-1073.

Vázquez, M., Fidalgo, L. G., Saraiva, J. A., \& Aubourg, S. P. (2018). Preservative effect of a previous high-pressure treatment on the chemical changes related to quality loss in frozen hake (Merluccius merluccius). Food and Bioprocess Technology, 11(2), 293-304. http://dx.doi.org/10.1007/s11947-017-2010-4

Veeck, A. P. D. L., Boligon, A. A., Athayde, M. L., \& Emanuelli, T. (2013). Mate extract on lipid and color changes of dourado fillets during frozen storage. Ciência Rural, 43(7), 1317-1322. http://dx.doi.org/10.1590/S0103-84782013005000079

Verrez-Bagnis, V., Noel, J., Sautereau, C., \& Fleurence, J. (1999). Desmin degradation in postmortem fish muscle. Journal of Food Science, 64(2), 240-242. http://dx.doi.org/10.1111/j.1365-2621.1999.tb15873.x

Wang, H., Luo, Y., Huang, H., \& Xu, Q. (2014). Microbial succession of grass carp (Ctenopharyngodon idellus) filets during storage at $4{ }^{\circ} \mathrm{C}$ and its contribution to biogenic amines' formation. International Journal of Food Microbiology, 190, 66-71. PMid:25194259. http://dx.doi.org/10.1016/j.ijfoodmicro.2014.08.021

Wang, P. A., Martinez, I., \& Olsen, R. L. (2009). Myosin heavy chain degradation during post mortem storage of Atlantic cod (Gadus morhua L.). Food Chemistry, 115(4), 1228-1233. http://dx.doi.org/10.1016/j.foodchem.2009.01.031

Wang, P. A., Vang, B., Pedersen, A. M., Martinez, I., \& Olsen, R. L. (2011). Post-mortem degradation of myosin heavy chain in intact fish muscle: Effects of pH and enzyme inhibitors. Food Chemistry, 124(3), 1090-1095. http://dx.doi.org/10.1016/j.foodchem.2010.07.093

Wang, S., Xiang, W., Fan, H., Xie, J., \& Qian, Y. F. (2018). Study on the mobility of water and its correlation with the spoilage process of salmon (Salmo solar) stored at 0 and $4{ }^{\circ} \mathrm{C}$ by low-field nuclear magnetic resonance (LF NMR 1H). Journal of Food Science and Technology, 55(1), 173-182. PMid:29358808. http://dx.doi.org/10.1007/s13197-017-2880-5

Yu, D., Xu, Y., Regenstein, J. M., Xia, W., Yang, F., Jiang, Q., \& Wang, B. (2018). The effects of edible chitosan-based coatings on flavor quality of raw grass carp (Ctenopharyngodon idellus) fillets during refrigerated storage. Food Chemistry, 242, 412-420. PMid:29037708. http://dx.doi.org/10.1016/j.foodchem.2017.09.037 